\title{
SAĞLIK ÇALIŞANLARINDA TEKNOSTRES: BİR ÖZEL HASTANE ÖRNEĞİ
}

\author{
Koray Kopuz* \\ Gamze Aydı***
}

Gönderim Tarihi: 15.08 .2020

Kabul Tarihi:

\section{Özet}

Stres, günümüzde hemen her sektörde olduğu gibi sağllk sektöründe de karşı karşıya kalınan bir sorundur. Bilgi ve iletişim teknolojilerindeki dönüşüm ile, sağlık çalışanları da örgütsel, çevresel ve kişisel nedenlerle stres yaratan unsurlarından etkilenmektedir. Bu stres kaynaklarından bir tanesi de teknolojiden kaynaklanan teknostres kavramıdır. Teknostres, bireylerin yeni teknolojilere adaptasyon sürecinde yaşadıkları stres olarak tanımlanabilir. Bu araştırmanın amacl; özel bir hastanede görev yapan 159 să̆lık çalışanının teknostres düzeylerinin belirlenmesidir. Bu kapsamda sağlık çalışanlarının sosyo-demografik özelliklerinin teknostres ve teknostres'in alt boyutları olan tekno aşırı-yüklenme, tekno-işgal, tekno-karmaşıklı, tekno-güvensizlik ve tekno-belirsizlik üzerindeki etkisi incelenmiştir. Araştırmada; erkek sağlık çalışanlarının kadınlara göre daha fazla teknostrese maruz kaldıkları, kurumda çalışma süreleri ile meslekte çalışma sürelerinin teknostres düzeylerini etkilemediği ve genç çalışanların ise yaşlı çalışanlara kıyasla daha fazla teknostres yaşadıkları tespit edilmiştir. Sonuçların hastane yöneticileri, insan kaynakları birimleri ve bilgi ve iletişim teknolojileri uzmanlarına uygulama süreçlerinde yardımcı olacă̆ı düşünülmektedir.

Anahtar Kelimeler: Teknostres, Sağlık Çalışanları, Bilgi ve İletişim teknolojileri

Jel Sinıflandırması: $O 39, I 1, D 80$.

\section{TECHNOSTRESS IN HEALTHCARE EMPLOYEES: A CASE OF A PRIVATE HOSPITAL}

\begin{abstract}
Stress is a problem faced in the health sector as in almost every sector today. With the transformation in information and communication technologies, healthcare professionals are also affected by factors that create stress for organizational, environmental and personal reasons. One of these stress sources is the concept of technostress caused by technology. Technostress can be defined as the stress that individuals experience during the adaptation process to new technologies. The purpose of this research is the determination of technostress levels of 159 healthcare workers working in a private hospital. In this context, the effects of socio-demographic characteristics of healthcare workers on techno-overload, techno-occupation, techno-complexity, techno-insecurity and techno-uncertainty, which are sub-dimensions of technostress, have been examined. In the study; it has been determined that male healthcare workers are exposed to techno-stress more than women, their working hours and working hours in the institution do not affect their techno-stress levels, and younger employees experience more techno-stress than older employees. The results are thought to help hospital managers, human resources units and information and communication technology specialists in their implementation processes.
\end{abstract}

\footnotetext{
* Arş. Gör., Niğde Ömer Halisdemir Üniversitesi, Niğde Zübeyde Hanım Sağlık Yüksekokulu, Sağlık Yönetimi Bölümü koraykopuz@gmail.com

** Öğr. Gör., İstanbul Arel Üniversitesi, Meslek Yüksekokulu, Büro Yönetimi ve Yönetici Asistanlığı Programı, gamzeaydin@arel.edu.tr
} 
Keywords: Technostress, Health Employees, Information and Communication Technologies

Jel Classification: $O 39, I 1, D 80$.

\section{Giriş}

Bir stres kaynağı olarak teknoloji, uzun bir dönem boyunca iş stresi araştırmalarının odağında olmamıştır. Ancak bu durum Bilgi İletişim Teknolojilerinin (BİT) dönüşümüyle değişmiştir. BİT neredeyse her sektör ve işkolunda mevcut hale gelmiştir. Diğer sektörlerde olduğu gibi sağlik hizmetleri sektöründe de yeni teknolojilerin kullanımı yoğunlaşmıştır (Göktaş vd., 2017: 127). Türkiye'de sağlık sektöründe yer alan hastanelerin teknoloji kullanımları incelendiğinde Sağlık Bilgi ve Yönetim Sistemleri Topluluğu (Healthcare Information and Management Systems SocietyHIMSS) tarafindan akredite edilen hastaneler buna örnek olarak gösterilebilir. . HIMSS, Elektronik Sağlık Kaydı Benimseme Modeli (Electronic Medical Record Adoption Model-EMRAM) ile hastanelerin dijital olma seviyeleri yedi kademe üzerinden denetlenerek akredite edilmektedir. Modele göre Türkiye'de 2020 yılı itibari ile 174 hastane 6. Seviye, 3 hastane de 7. seviyede yer almaktadır. Bu sayılar ile Türkiye, Avrupa ve bölge liderliğini sürdürmektedir. Dolayısı ile bu durum Türkiye'deki hastanelerin dijital olma seviyesini ve artan BİT kullanımının mevcut durumunu göstermektedir (HIMSS, 2020). BİT'in optimum düzeyde kullanılması, yüksek verimlilik, düşük maliyet, çalışanların motivasyonunu yükseltme, hasta bakım kalitesini artırma, yanlış tıbbi uygulamaları engelleme gibi olumlu etkilere sahiptir (Göktaş vd., 2017: 127; Mahboob ve Khan, 2016: 29). Örneğin, e-postaları yalnızca belirli zamanlarda kontrol etmek dahi, stresi azaltmakta ve kişinin mental iyi oluşunu arttırmaktadır (Kushlev ve Dunn, 2015). Dolayısı ile dijitalleşen sağlık sektöründe teknolojinin kullanımı ve yönetimi bu açıdan oldukça önemli görülmektedir.

BİT'teki değişimlerin organizasyon yapıları, iş modelleri ve istihdam ilişkileri üzerinde de çeşitli etkileri mevcuttur (Dragano ve Lunau, 2020: 407). Yeni teknolojiler sayesinde bilgiye çok kolay ve hızlı bir şekilde ulaşılmakta, arkadaşlar ve aileler ile aynı anda iletişim kurulabilmektedir. Geniş perspektiften bakıldığında bu tür teknolojiler örgütsel performansımızı da arttırmaktadır. Ancak çeşitli olumlu etkilerine rağmen, bu gelişmiş teknolojilerin kullanımından kaynaklanan birçok olumsuz yön tanımlanmıştır (Latorre vd., 2019: 13). BİT kaynaklı yeniliklerin yaygınlığı, çalışanların daha hızlı çalışmasını, yeni görevlere atanabilmeleri için sürekli olarak çalışmaya hazır durumda bulunmalarını ve e-posta veya cep telefonlarıyla zaman ve mekândan bağımsız olarak iletişime geçebilmelerini zorunlu kılmaktadır. Bu nedenle, çalışanlar aynı anda birden fazla görevle başa çıkmak, görevlerini yerine getirmek için BİT'i öğrenmek, kullanmak ve ofis dişındayken bile ani taleplere cevap vermek için bir tür zorunluluk hissetmektedirler (Güğerçin, 2020: 827). Bu zorunluluklar, teknolojinin toplum üzerindeki etkileriyle ilgili endişe duyma ve teknolojiyi kullanma korkusu olarak ifade edilen teknofobi (technophobia) (Nimrod, 2018: 148); çevrimiçi alışveriş, kumar ve oyun gibi bireylerin belirli bir ödüllendirici davranış üzerindeki kendini denetleme becerilerini kaybetmesi olarak ifade edilen teknoloji bağımlılığı (technology addiction) gibi kavramları da ortaya çıkarmıştır (Zwanenburg, 2013: 2). Bu kavramlardan biri de teknolojiden kaynaklanan stres olarak ifade edilen teknostres kavramıdır.

$\mathrm{Bu}$ kapsamda, sınırlı çalışmaların olduğu ve teknolojinin yoğun olarak kullanıldığı sağlık sektöründeki sağlık çalışanlarının teknostres düzeylerinin belirlenmesi hedeflenmiştir. Ayrıca sağlık çalışanlarının teknostres düzeylerinin; yaş, cinsiyet, meslek, kurumda ve meslekte çalışması süresi, teknoloji ile ilgili eğitim alma, öğrenim düzeyi, gelir gibi çeşitli demografik, çevresel ve mesleki faktörler tarafından nasıl etkilendiğinin tespit edilmesi amaçlanmıştır. 


\section{Teknostres}

Teknostres (technostress) ilk olarak 1984 yılında klinik psikolog Craig Brod tarafından "yeni bilgisayar teknolojilerine uyumsuzluk sonucu ortaya çıkan adaptasyon hastalığı" olarak ifade edilmiş olup; "teknoloji kaynaklı psikolojik ve fizyolojik olumsuz etkiler" olarak tanımlanabilir (Çiçek ve Kılınç, 2020: 556). Teknostresle sıkça karıştırılan kavramlardan teknofobi, teknolojiyi kullanma korkusuyla ilişkiliyken; teknostres, bireylerin teknoloji kullanımı ile ilgili zorluklarla başa çıkamadıklarında yaşadıkları bir uyum sorunudur. Ayrıca teknostres sadece teknolojiyle değil, aynı zamanda teknolojinin kullanımından kaynaklanan, öğrenmenin süreçleri ve değerlendirilmesi gibi birçok alanında değişen gereksinimlerle de ilgilidir (Wang, Tan ve Li, 2020: 97). Başka bir deyişle teknostres, teknoloji kullanımının getirdiği insan davranışları, düşünceleri, tutumları ve psikolojisi üzerindeki olumsuz etkilerdir (Nisafani, Kiely ve Mahony, 2020: 2). Bireylerin sürekli gelişen BİT kullanımlarının getirdiği fiziksel, sosyal ve bilişsel gereklilikleri karşılayabilme girişimlerinden doğan teknostres kavramı, literatürde çeşitli sınıflandırmalara tabi tutulmuştur. Yaygın kabul gören sınıflandırmalardan birine göre teknostres; tekno-aşırı yükleme, tekno-işgal, tekno-karmaşıklık, tekno-güvensizlik ve tekno-belirsizlik olmak üzere beş boyuttan oluşmaktadır (Tarafdar vd., 2007: 418; Ayyagari vd., 2011).

Tekno-Aşırı Yükleme (Techno-Overload): Mobil bilgi işlem cihazlarının sosyal ağ ve uygulamalarla senkronize halde çalışmasının getirdiği aşırı bilgi yükü ile aynı anda birden fazla işi yapabilmeyi ifade eder. Aşırı bilgi yükü, aynı anda farklı uygulamalar ve görevler üzerinde çalışarak, daha az zamanda daha çok işi birlikte yürütmeye çabalayan bireylerde kaygı ve gerginlik yaratmaktadır. Çalışanların iş yorgunluğu ve diğer sağlık sorunları yaşamasına neden olabilir. İş yerinin ergonomik açıdan kötü tasarımı, vücut hareketleri ve diğer ergonomik tehlikeler çok sayıda kümülatif travma bozukluğuna yol açabilir. Bu durum tekno-aşırı yüklemeyi ifade etmektedir (Christian, Purwanto ve Wibowo, 2020: 2800; Tarafdar vd., 2011: 116).

Tekno-İşgal (Techno-Invasion): Çalışanların çalışma saatlerinin aileleri ile geçirecekleri (tatil günleri dâhil) zamana kadar taşması ve sürekli bağlantı halinde olmanın yarattığı gerginliği ifade eder. Teknoloji ile sürekli temas halinde kalarak çalışmak, bireylerin aileleri ve arkadaşları için yeterli zamanı bulmaları konusunda kendilerini eksik hissetmelerine neden olur (Khan, Jamil ve Bakhsh, 2020: 316; Tarafdar vd., 2011: 116). Bu doğrultuda tekno-işgal boyutu çalışanlara takılan bir tür sanal tasma olarak nitelendirilebilir (Sellberg ve Susi, 2014: 189).

Tekno-Karmaşıklık (Techno-Complexity): Güncel donanım, yazılım ve uygulamaları kullanma baskısı arttıkça bu uygulamalara ilişkin teknik özellikler ve terminoloji daha da karmaşık hale gelmiştir. Bu durum tekno-karmaşıklığı ifade eder. Yeni uygulamaların öğrenilmesi aylar alabilir ve kılavuzlar yeteri kadar anlaşılır ya da kullanışlı olmayabilir. Böylece kullanıcılar çeşitli uygulamalar, işlevler ve jargonlar bulabilir dolayısıyla stresli hissedebilirler (Tarafdar vd., 2011: 117).

Tekno-Güvensizlik (Techno-Insecurtiy): İşverenlerin güncel uygulamaları daha iyi ve çabuk kavrayan çalışanları tercih etmeleri mevcut çalışanlarda gerginlik yaratabilir. Son teknolojiyi kendilerinden daha iyi takip eden çalışanlar karşısında bireyler kendilerini güvensiz hissedebilirler. Yeterli bilgi ve operasyon becerilerine sahip olamayan ve yeni teknolojik becerileri öğrenemeyen çalışanlar, sürekli olarak kendilerini yeni teknolojik becerilerle güncelleme eğiliminde olduklarından, sürekli olarak baskı altında kalmakta ve nispeten daha iyi bir anlayışa sahip yetenekli kişilerle yer değiştirme korkusunu hissetmektedirler. Bu durum teknolojinin yarattığı güvensizlik ortamını ifade etmekte ve tekno-güvensizlik olarak adlandırılmaktadır (Khan, Jamil ve Bakhsh, 2020: 316; Tarafdar vd., 2011: 116).

Tekno-Belirsizlik (Techno-Uncertainity): Çalışanların sahip olduğu mevcut bilginin yeni bilgilerle değiştirilmesi tehdidi her zaman belirsizliğe neden olmaktadır (Khan, Jamil ve Bakhsh, 2020: 316). Bireyler her ne kadar başlangıçta bu yeni teknolojileri kullanmak için hevesli olsalar da teknolojik 
yeniliklerin hızla eskimesi ile hayal kırıklığı ve endişe yaşamaktadırlar. Ayrıca uygulamalar için belirli bazı politik süreçleri içeren yapılandırmalar ve özelleştirmeler gerekir. Uygulamaya konulduktan sonra bile, çalışanlar bunları kullanma konusunda kaygı duyarlar çünkü uygulamaların benimsenmesi zaman alır ve bilgi işlem departmanlarının verdiği destek yetersiz kalabilir. $\mathrm{Bu}$ durum ise tekno-belirsizlik olarak ifade edilmiştir (Tarafdar vd., 2011: 117).

Önceki araştırmalarda teknostresin iki yönüne odaklanılmıştır. Bunlar teknostres yaratan faktörler (technostressors) ve teknostresin sonuçları (technostress outcomes) dır (Salo, Pirkkalainen, Chua ve Koskelainen, 2017: 2461-2462). Teknostresör olarak; teknolojik yenilikler, ekonomik krizler, rekabet baskısı, yüksek enflasyon, politik istikrarsızlık gibi faktörlerin çalışanların yaşam ve iş ortamlarının geleceğini belirsiz hale getirmesi sayılabilir (Keleş, 2019: 14). Sağlık çalışanları özelinde bakıldığında ise, sağlık bilişimi veya tıbbi bilişim; bilgi bilimi, bilgisayar bilimi ve sağlık hizmetlerinin kesişimi olarak nitelendirilebilir. BİT çatısı altında, sağlık bilişim sistemlerinin insan sağlığını en iyi duruma getirmek için gereken kaynakları, cihazları ve yöntemleri kapsayan bir alt sistem olduğu görülmektedir. Sağlık bilişsimi araçları yalnızca bilgisayarları değil aynı zamanda klinik kılavuzları, resmi tıbbi terminolojileri de içerir (Çoban, 2019: 26). Bu kapsamlı yeniliklerin sağlık çalışanları üzerindeki baskısı kaçınılmazdır.

Teknostresin çalışanlar üzerindeki sonuçları ise; davranışsal, psikolojik veya fizyolojik olarak gruplanabilir (Weinert, Christian, Laumer ve Weitzel, 2020: 4; Akgün, 2019: 43; Yener, 2018: 88); davranışsal açıdan; düşük performans, hatalar, işte var olmama ve işgören devri; psikolojik açıdan; iş tatmini ve tükenmişlik, endişe, kaygı, şüphecilik, yorgunluk, teknolojiye bağımlılık, motivasyon düşmesi; fizyolojik açıdan ise; sırt ağrıları, baş ağrıları, kan basıncının yükselmesi gibi semptomlar şeklinde sayılabilir.

\section{Literatür Taraması ve Hipotez Geliştirme}

Genel olarak stres üzerine yapılan çalışmalar tıp, psikoloji, yönetim ve sosyoloji gibi farklı disiplinlerin araştırma geleneklerini birleştiren araştırma tasarımlarına ihtiyaç duymaktadır. Teknostres de özünde multidisipliner araştırmalara ihtiyaç duyar (Fischer ve Riedl, 2017: 376). Bu doğrultuda literatürde yapılmış çeşitli araştırmalar bulunmaktadır. Bu çalışmalarda teknostres, ağırlıklı olarak eğitim, kütüphane, bankacılık ve sosyal medya alanlarında araştırılmıştır (Kaymaz, 2019; La Torre vd., 2019; Keleş, 2018; Çetin, 2017; Çoklar vd., 2016; Çoklar ve Şahin, 2011; Şahin ve Çoklar, 2009). Ancak sağlık alanındaki teknostres araştırmaları bu alanlara göre daha azdır (Çoban, 2019; Doğrular, 2019).

Literatürde teknostresin demografik, mesleki ve çevresel değişkenlerle ilişkisini ele alan birçok çalışma bulunmaktadır. Bu çalışmalar arasında cinsiyet değişkenin teknostres düzeyi üzerinde ilişkisini ortaya koyan çalışmalar mevcuttur (La Torre vd., 2019; Çoklar ve Şahin, 2011; Tarafdar vd., 2011; Ragu-Nathan vd., 2008). Bazı çalışmalarda ise teknostresin alt boyutlarının cinsiyet tarafından etkilendiği bulunmuştur (Akgün, 2019; Kaymaz, 2019; Sever ve Sever, 2017; Türen vd., 2015). Ayrıca sağlık sektöründe yapılan bazı çalışmalarda da yine cinsiyetin sağlık çalışanlarının teknostres düzeyleri üzerinde etkili olduğu tespit edilmiştir (Doğrular, 2019). İncelenen bu çalışmaların çoğunda erkeklerin teknostres ve tekno-işgal düzeylerinin kadınlara göre daha fazla olduğu gözlemlenmiştir (Akgün, 2019; Doğrular, 2019; Kaymaz, 2019; Tarafdar vd., 2011; RaguNathan vd., 2008). Bazı çalışmalarda da kadınların teknostres ve tekno-belirsizlik düzeylerinin erkeklere göre daha fazla olduğu gözlemlenmiştir (Sever ve Sever, 2017; Türen vd., 2015; Çoklar ve Şahin, 2011). İncelenen bu çalışmalar doğrultusunda sağlık çalışanlarının cinsiyetlerinin teknostres seviyeleri üzerindeki etkisini incelemek amacı ile oluşturulan ilk hipotez şu şekildedir.

$\mathbf{H}_{1}$ : Çalışmaya katılanların teknostres düzeyleri cinsiyetlerine göre istatistiksel olarak anlamlı bir şekilde farklılaşmaktadır. 
Literatür incelendiğinde ortaya çıkan bir diğer konu ise teknoloji eğitimidir. Eğitim alan kişilerin bilgisayar kullanımını daha başarılı bir şekilde gerçekleştirdiği tespit edilmiştir. Daha eğitimli kullanıcıların daha az eğitimli olanlara göre bilgisayar kullanımı konusunda önemli ölçüde iyi performans gösterdiği açıktır (Davis ve Davis, 1990). Teknostresi azaltmanın en önemli yollarından bir tanesi de eğitimdir. Kullanıcıları yeni gelişmeler konusunda eğitmek gerekir. Bu sayede değişime direnç azalmakta ve bu durum da teknostresin artışını engellemeye katkıda bulunmaktadır (Sami ve Pangannaiah, 2006: 434). Okul yöneticileri ile yapılan bir çalışmada da teknoloji ile ilgili eğitim alan yöneticilerin teknostres düzeylerinin almayanlara göre anlamlı bir şekilde farklılaştığ1 görülmüştür. Eğitim alanların puan ortalamaları eğitim almayanlara göre daha yüksek olarak tespit edilmiştir (Çetin ve Bülbül, 2017). Dolayısı ile sağlık alanında teknoloji ile ilgili bir eğitim almış olmanın teknostres düzeyini etkileyip etkilemediğini test etmek amacı ile oluşturulan hipotez şu şekildedir.

$\mathbf{H}_{2}$ : Çalışmaya katılanların teknostres düzeyleri teknoloji ile ilgili bir eğitim alıp almamasına göre istatistiksel olarak anlamlı bir şekilde farklılaşmaktadır.

Öğrenim düzeyinin kişilerin teknostres düzeylerini etkileyip etkilemediği incelendiğinde, öğrenim düzeyinin kişilerin teknostres, tekno-aşırı yükleme, tekno-belirsizlik ve tekno-karmaşıklık düzeylerini etkilediği görülmüştür (Kaymaz, 2019; La Torre vd., 2019; Hsiao, 2016; Türen vd., 2015; Tarafdar vd., 2011; Ragu-Nathan vd., 2008) İncelenen çalışmalar doğrultusunda sağlık alanında öğrenim düzeyinin sağlık çalışanlarının teknostres düzeylerini etkileyip etkilemediğini test etmek amacı ile oluşturulan hipotez şu şekildedir.

H3: Çalışmaya katılanların teknostres düzeyleri öğrenim düzeylerine göre istatistiksel olarak anlamlı bir şekilde farklılaşmaktadır.

Teknostresi etkileyen bir diğer faktör olarak kişilerin görevleri ve meslekleri ortaya konulmuştur. Literatürde yer alan çalışmalarda çalışanların teknostres düzeylerinin mesleklerine göre anlamlı bir şekilde farklılaştığı tespit edilmiştir (Kaymaz, 2019; La Torre vd., 2019; Türen vd., 2015, Çoklar ve Şahin, 2011). Bu kapsamda sağlık çalışanlarının mesleklerine göre teknostres düzeylerinin farklılaşıp farklılaşmadığını sınamak amacıyla şu hipotez oluşturulmuştur.

$\mathbf{H}_{4}$ : Çallşmaya katılanların teknostres düzeyleri mesleklerine göre istatistiksel olarak anlamlı bir şekilde farklılaşmaktadır.

Literatürde kişilerin aylık gelirleri ile teknostres düzeyleri arasında bir ilişkinin olduğu ve teknostres düzeylerinin gelir gruplarına göre farklılaşabileceği öne sürülmüştür. Yapılan çalışmalarda da bu durum doğrulanmış ve teknostres ile aylık gelir ilişkisi ortaya konulmuştur. Aylık geliri fazla olan kişilerin daha düşük teknostres ve tekno-belirsizlik düzeyine sahip olduğu ve aylık gelirin teknostres ile negatif yönlü bir ilişki içinde olduğu tespit edilmiştir (Çoban, 2019; La Torre, 2019; Hsiao, 2016; Şahin ve Çoklar, 2009). Dolayısı ile sağlık çalışanlarının teknostres düzeylerinin aylık gelirlerine göre farklılaşmasının araştırılması amacıyla aşağıdaki hipotez oluşturulmuştur.

H5: Çalışmaya katılanların teknostres düzeyleri aylık gelirlerine göre istatistiksel olarak anlamlı bir şekilde farklılaşmaktadır.

Literatürde ayrıca teknostresin ve alt boyutlarının kişilerin kurumda ve meslekte çalışma süreleri ile ilişkili olabileceği ifade edilmektedir. Bu doğrultuda yapılan çalışmalar sonucunda kişilerin teknostres, tekno-işgal, tekno-belirsizlik ve tekno-karmaşıklık seviyeleri ile kurumda ve meslekte çalışma süreleri arasında ilişki olduğu tespit edilmiştir (Kaymaz, 2019; Çetin ve Bülbül, 2017). Bu doğrultuda sağlık çalışanlarının meslekte ve kurumda çalışma sürelerinin teknostres düzeyleri ile ilişkisini test etmek amaciyla aşağıdaki iki hipotez oluşturulmuştur.

H6: Çalışmaya katılanların teknostres düzeyleri ile mevcut kurumda çalışma süreleri arasında istatistiksel olarak anlamlı bir ilişki vardır. 
H7: Çalışmaya katılanların teknostres düzeyleri ile meslekte çalışma süreleri arasında istatistiksel olarak anlamlı bir ilişki vardır.

Literatürdeki çalışmalar teknostresin kişilerin yaşları ile ilişkili olduğu ve kişilerin yaş gruplarının teknostres düzeylerini etkilediğini göstermektedir (La Torre vd., 2019; Özbozkurt, 2019; Çoklar ve Şahin, 2011; Tarafdar vd., 2011; Şahin ve Çoklar, 2009; Ragu-Nathan vd., 2008). Bazı çalışmalarda da teknostresin alt boyutlarının yaş ile ilişkili olduğu tespit edilmiştir (Kaymaz, 2019; Çetin ve Bülbül, 2017). Bu çalışmalar incelendiğinde, yaşın arttıkça teknostres, tekno-karmaşıklık ve teknobelirsizlik düzeylerinin azaldığı görülmüştür (Özbozkurt, 2019; Çetin ve Bülbül, 2017; Çoklar ve Şahin, 2011; Tarafdar vd., 2011; Şahin ve Çoklar, 2009; Ragu-Nathan vd., 2008). Yaş arttıkça daha düşük teknostress seviyelerinin olmasının yaşam boyu deneyimleriyle ilişkilendirilebileceği öne sürülmüştür (Şahin ve Çoklar, 2009). Bu çalışmalar doğrultusunda yaş ve teknostres arasındaki ilişkiyi incelemek üzere oluşturulan son hipotez şu şekildedir.

H8: Çalışmaya katılanların teknostres düzeyleri ile yaşları arasında istatistiksel olarak anlamlı bir ilişki vardir.

\section{Yöntem}

Sağlık çalışanlarının teknostres düzeylerinin belirlenmesi ve çeşitli demografik, mesleki ve çevresel faktörlerin teknostres düzeyleri üzerindeki etkisinin incelenmesini amaçlayan bu araştırma İstanbul ilinde yer alan bir özel hastanede gerçekleştirilmiştir.

Araştırma, amacı açısından tanımlayıcı ve zaman boyutu açısından kesitsel tipte bir araştırma olarak tasarlanmıştır. Araştırma evrenini, İstanbul'da bir özel hastanede çalışan tüm sağlık çalışanları (220 sağlık çalışanı) oluşturmaktadır. Araştırma kapsamında örneklem belirleme yoluna gidilmemiş ve sağlık çalışanlarının tamamına ulaşılmaya çalışılmıştır. Özel hastanede çalışan 220 sağlık çalışanının 159'u (\%72) araştırmaya katılmıştır. Araştırmaya katılan sağlık çalışanlarının sosyodemografik verilerinin dağılımı Tablo 1'de sunulmuştur.

Tablo 1: Katılımcılara Ait Sosyo-Demografik Verilerin Dağılımı

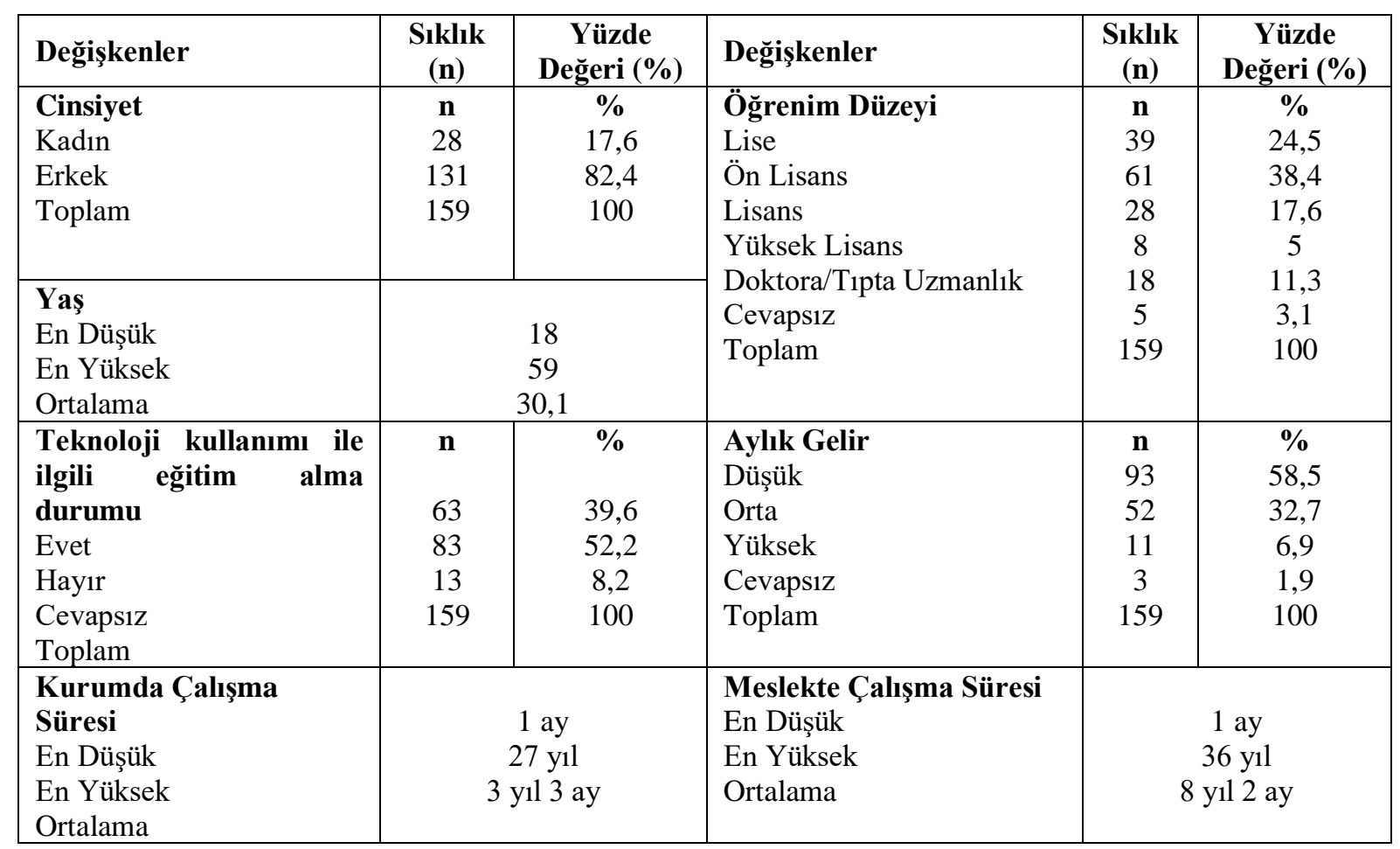


Tablo 1(Devamı): Katılımcılara Ait Sosyo-Demografik Verilerin Dağılımı

\begin{tabular}{|l|c|c|}
\hline Meslek & $\mathbf{n}$ & $\mathbf{\%}$ \\
Hekim & 21 & 13,2 \\
Hemşire & 62 & 39 \\
Yrd. Sağlık Personeli & 9 & 5,7 \\
İdari Görevli & 13 & 8,2 \\
Hasta Kayıt Yetkilisi & 13 & 8,2 \\
Hasta Danışmanı & 16 & 10,1 \\
Ebe & 2 & 1,3 \\
Cevapsız & 23 & 14,4 \\
Toplam & 159 & 100 \\
\hline
\end{tabular}

Çalışmaya katılan sağlık çalışanlarının demografik verileri incelendiğinde; \%82,4'ünün kadın, \%38,4'ünün ön lisans mezunu, \%39'unun hemşire olduğu görülmüştür. Katılımc1ların \%58,5'i gelirini düşük olarak ifade etmektedir. Ayrıca katılımcıların \%52,2'si daha önce teknoloji kullanımı ile ilgili herhangi bir eğitim almamıştır. Katılımcıların yaş ortalaması 30 iken, mevcut kurumda çalışma süresi ortalama 3 yıl 3 ay, meslekte çalışma süresi ise ortalama 8 yıl 2 ay olarak tespit edilmiştir.

Araştırmada veri toplama aracı olarak anket yöntemi kullanılmıştır. Anket formu iki bölümden oluşmaktadır. Anket formunun birinci bölümünde katılımcıların teknostres düzeylerini ölçmek için 14 sorudan oluşan ve Tarafdar (2007) tarafından geliştirilen, Türen vd., (2015) tarafından Türkçeye uyarlanan "İş Yerinde Tekno-Stres Ölçeği” kullanılmıştır. Bu ölçek 5'li likert tipinde tasarlanmıştır. (1=Hiç Katılmıyorum 5=Kesinlikle Katılıyorum). Ölçek tekno-aşırı yükleme, tekno-belirsizlik ve tekno-karmaşıklık olmak üzere üç alt boyuttan oluşmaktadır. Anket formunun ikinci bölümünde ise katılımcıların sosyo-demografik bilgilerini elde etmeye yönelik 8 soru sorulmuştur. Ölçeğin ve alt boyutlarının iç tutarlılı̆̆ını ölçmek amacı ile Cronbach Alpha $(\alpha)$ değerleri ve ölçeğin faktörlerinin belirlenmesi için yapılan faktör analizinin sonuçlarına Tablo 2'de yer verilmiştir.

Tablo 2: Teknostres Ölçeğinin Faktör Yapısı ve Güvenilirlik Değerleri

\begin{tabular}{|c|c|c|c|}
\hline & \multicolumn{3}{|c|}{ Faktörler } \\
\hline Ölçeğe Ait İfadeler & Tekno-Aşırı Yükleme & Tekno-Karmaşıklık & Tekno-Belirsizlik \\
\hline S3 & 0,852 & & \\
\hline S1 & 0,845 & & \\
\hline S2 & 0,834 & & \\
\hline S4 & 0,804 & & \\
\hline S5 & 0,680 & & \\
\hline S7 & & 0,820 & \\
\hline S10 & & 0,803 & \\
\hline S8 & & 0,785 & \\
\hline S6 & & 0,666 & \\
\hline S9 & & 0,396 & \\
\hline S13 & & & 0,888 \\
\hline S12 & & & 0,878 \\
\hline S14 & & & 0,872 \\
\hline S11 & & & 0,546 \\
\hline Varyans $(\%)$ & 30,92 & 19,88 & 12,99 \\
\hline Faktörlerin $\alpha$ Değerleri & 0,879 & 0,758 & 0,819 \\
\hline Genel Ölçek $\alpha$ Değeri & & 0,806 & \\
\hline
\end{tabular}


Yapılan KMO ve Bartlett testi sonucunda KMO değerinin 0,790 bulunması ve Bartlett küresellik testi $p$ değerinin 0,05 'ten küçük olması $(p=0,00)$ verilerin faktör analizine olan uygunluğunu göstermiştir (Kaptanoğlu, 2013: 239). Yapılan faktör analizi sonucunda herhangi bir binişik madde olmadığından veya herhangi bir ifadenin faktör yükünün 0,30'un altında kalmadığından ölçekten ifade çıkarımı yapılmamıştır (Kaptanoğlu, 2013: 240-241). Teknostres ölçeği toplam varyansı \%63,80 olan üç faktöre ayrılmıştır. Teknostres ölçeği faktör yükleri ve faktörler altında yer alan ifadeler Tablo 2'de belirtilmiştir.

Araştırmada kullanılan ölçeğin ve alt boyutlarının iç tutarlılığını ölçmek amacı ile Cronbach Alpha ( $\alpha$ ) değerleri hesaplanmıştır. Güvenilirlik katsayısının 0,70 veya üzerinde olması puanları güvenilirliği için yeterli görülmektedir. Ölçek ve alt boyutlarının tamamında Cronbach Alpha $(\alpha)$ değeri 0,70'in üzerinde bulunmuş ve Tablo 2'de gösterilmiştir. Bundan dolayı ölçeğin güvenilir olduğu söylenebilir (Durmuş vd., 2016: 89).

Veriler 20 Ağustos 2019 ve 20 Eylül 2019 tarihleri arasında toplanmıştır. Onam belgesi her katılımcıya anket formunun üzerinde yazılı olarak sunulmuştur. Anketin uygulama yanlılığını azaltmak amacı ile anketler kapalı zarflarda dağıtılmış ve kapalı zarflarda toplanmıştır.

Araştırmadan elde edilen veriler SPSS (Statistical Package for Social Sciences) for Windows 22 istatistik paket programında analiz edilmiştir. Analiz ve değerlendirmeler yapılmadan önce değişkenlerin normal dağılıma uyup uymadığını değerlendirmek amacı ile elde edilen puanların histogramları çizilip basıklık ve çarpıklık değerleri incelenmiş ayrıca One Sample KolmogorowSmirnow testi yapılmıştır. İnceleme sonucunda basıklık değeri 0,135 çarpıklık değeri 0,311 olarak belirlenmiştir. Ayrıca One Sample Kolmogorow-Smirnow testi sonucu p değeri 0,200 olarak tespit edilmiştir. Basıklık ve çarpıklık değerlerinin $+1,5$ ile $-1,5$ arasında olması ve One Sample Kolmogorow-Smirnow testi sonucunun anlamsız çıkması verilerin normal dağıldığını göstermektedir (Tabachnick vd, 2013). Dolayısı ile çalışmanın tamamında parametrik hipotez testlerinden; pearson korelasyon testi, bağımsız gruplar $t$ testi, tek yönlü varyans analizi (ANOVA) kullanılmış ve istatistiksel anlamlılık düzeyi 0,05 olarak kabul edilmiştir. Ayrıca çalışmadaki soru gruplarının faktör yapısını tespit etmek amacı ile açımlayıcı faktör analizi uygulaması yapılmış ve boyutların iç tutarlılığının test edilmesi amacı ile de Cronbach Alpha analizi kullanılmıştır.

\section{Bulgular}

Çalışmanın bu kısmında hipotezlerin test edilmesi amacıyla yapılan analiz sonuçlarına yer verilmiştir.

\subsection{Hipotezlerin Test Edilmesi}

Çalışmanın hipotezlerini test etmek üzere yapılan analizlerin sonuçlarına, teknostres ölçeği ve alt boyutlarının puan ortalamalarına aşağıdaki tablolarda yer verilmiştir. Tablo 3 'te teknostres ölçeği ve alt boyutlarının puan ortalamalarına yer verilmiştir.

Tablo 3: Teknostres Ölçeği ve Alt Boyutlarının Puan Ortalamaları

\begin{tabular}{|l|c|c|c|}
\hline Değişkenler & Sayı (n) & Ortalama $(\overline{\mathbf{x}})$ & Standart Sapma (ss) \\
\hline Tekno-Karmaşıklı* & 159 & 2,23 & 0,73 \\
\hline Tekno-Belirsizlik* & 159 & 2,83 & 0,88 \\
\hline Tekno-Așırı Yükleme* & 159 & 2,54 & 0,97 \\
\hline Teknostres** & 159 & 2,52 & 0,59 \\
\hline
\end{tabular}

** Genel ölçek *Alt boyut

Teknostres ölçeği genel puan ortalaması $(2,52 \pm 0,59)$ olarak bulunmuştur. Ölçeğin alt boyutları arasında en yüksek ortalamayı tekno-belirsizlik $(2,83 \pm 0,88)$ alırken, sonrasında sırasıyla tekno-aşırı yükleme $(2,54 \pm 0,97)$ ve tekno-karmaş1klık $(2,23 \pm 0,73)$ gelmektedir. 
Katılımcıların teknostres, tekno-karmaşıklık, tekno-belirsizlik ve tekno-aşırı yükleme puan ortalamalarının katılımcıların cinsiyetine göre anlamlı bir şekilde farklılaşıp farklılaşmadığını belirlemek üzere bağımsız gruplarda t testi yapılmıştır. Bu analizin sonuçlarına Tablo 4'te yer verilmiştir.

Tablo 4: Cinsiyetin Tekno-Aşırı Yükleme, Tekno-Belirsizlik, Tekno-Karmaşıklık ve Teknostres Üzerindeki Etkisi

\begin{tabular}{|c|c|c|c|c|c|c|c|c|}
\hline \multirow{2}{*}{ Kategori } & \multicolumn{2}{|c|}{$\begin{array}{l}\text { Tekno-Aşırı } \\
\text { Yükleme }\end{array}$} & \multicolumn{2}{|c|}{ Tekno-Belirsizlik } & \multicolumn{2}{|c|}{ Tekno-Karmaşıklık } & \multicolumn{2}{|c|}{ Teknostres } \\
\hline & $\overline{\mathbf{x}}$ & Ss & $\overline{\mathbf{x}}$ & SS & $\overline{\mathbf{x}}$ & SS & $\overline{\mathbf{x}}$ & SS \\
\hline Kadın & 2,61 & 0,99 & 2,76 & 0,87 & 2,22 & 0,74 & 2,51 & 0,60 \\
\hline Erkek & 2,24 & 0,79 & 3,15 & 0,87 & 2,29 & 0,69 & 2,52 & 0,50 \\
\hline$t$ değeri & \multicolumn{2}{|c|}{$-1,849$} & \multicolumn{2}{|c|}{2,106} & \multicolumn{2}{|c|}{0,438} & \multicolumn{2}{|c|}{0,009} \\
\hline p değeri & \multicolumn{2}{|c|}{0,660} & \multicolumn{2}{|c|}{$\mathbf{0 , 0 3 7}$} & \multicolumn{2}{|c|}{0,662} & \multicolumn{2}{|c|}{0,993} \\
\hline
\end{tabular}

Yapılan bağımsız gruplarda $t$ testi sonucunda, katılımcıların tekno-belirsizlik puan ortalamalarının cinsiyete göre istatistiksel olarak anlamlı bir şekilde farklılaştığ görülmüştür $(t=2,106 ; p<0,05)$. Erkeklerin tekno-belirsizlik puan ortalamasının $(\overline{\mathrm{x}}=3,15)$ kadınlara $(\overline{\mathrm{x}}=2,76)$ göre daha yüksek olduğu görülmüştür. Tekno-karmaşıklık ve tekno-aşırı yükleme alt boyutları ile genel teknostres puan ortalamasının cinsiyete göre istatistiksel olarak anlamlı bir fark göstermediği tespit edilmiştir ( $\mathrm{p}>0,05)$. Bu sonuçlar doğrultusunda, $\mathbf{H}_{1}$ hipotezi kısmen desteklenmiştir.

Katılımcıların teknostres, tekno-karmaşıklık, tekno-belirsizlik ve tekno-aşırı yükleme puan ortalamalarının, katılımcıların teknoloji ile ilgili herhangi bir eğitim alıp almamasına göre farklılaşıp farklılaşmadığını belirlemek amacıyla bağımsız gruplarda t testi yapılmıştır. Bu analizin sonuçlarına Tablo 5 'te yer verilmiştir.

Tablo 5: Teknoloji Eğitiminin Tekno-Aşırı Yükleme, Tekno-Belirsizlik, Tekno-Karmaşıklık ve Teknostres Üzerindeki Etkisi

\begin{tabular}{|l|c|c|c|c|c|c|c|c|}
\hline \multirow{2}{*}{ Kategori } & \multicolumn{2}{|c|}{$\begin{array}{c}\text { Tekno-Așırı } \\
\text { Yükleme }\end{array}$} & \multicolumn{2}{c|}{ Tekno-Belirsizlik } & \multicolumn{2}{c|}{ Tekno-Karmaşıklık } & \multicolumn{2}{c|}{ Teknostres } \\
\cline { 2 - 9 } & $\overline{\mathbf{x}}$ & ss & $\overline{\mathbf{x}}$ & Ss & $\overline{\mathbf{x}}$ & ss & $\overline{\mathbf{x}}$ & ss \\
\hline Evet & 2,44 & 1,00 & 2,88 & 0,91 & 2,08 & 0,68 & 2,44 & 0,56 \\
\hline Hayır & 2,60 & 0,91 & 2,82 & 0,89 & 2,32 & 0,074 & 2,56 & 0,59 \\
\hline t değeri & \multicolumn{2}{|c|}{$-1,017$} & \multicolumn{2}{|c|}{0,423} & \multicolumn{2}{|c|}{$-1,962$} & \multicolumn{2}{|c|}{$-1,27$} \\
\hline p değeri & \multicolumn{2}{|c|}{0,311} & \multicolumn{2}{c|}{0,673} & \multicolumn{2}{c|}{0,520} & \multicolumn{2}{c|}{0,206} \\
\hline
\end{tabular}

Katılımcıların teknoloji ile ilgili eğitim alıp almama durumuna göre teknostres puan ortalamaları ve teknostres alt boyut puan ortalamaları istatistiksel olarak anlamlı bir fark göstermemektedir ( $p>0,05)$. Bu sonuçlar doğrultusunda, $\mathbf{H}_{2}$ hipotezi reddedilmiştir.

Katılımcıların teknostres, tekno-karmaşıklık, tekno-belirsizlik ve tekno-aşırı yükleme ortalamalarının, katılımcıların öğrenim düzeylerine göre farklılaşıp farklılaşmadığını belirlemek amacıyla tek yönlü varyans analizi yapılmıştır. Bu analizin sonuçlarına Tablo 6'da yer verilmiştir. 
Tablo 6: Öğrenim Düzeyinin Tekno-Aşırı Yükleme, Tekno-Belirsizlik, Tekno-Karmaşıklık ve Teknostres Üzerindeki Etkisi

\begin{tabular}{|c|c|c|c|c|c|c|c|c|}
\hline \multirow{2}{*}{ Kategori } & \multicolumn{2}{|c|}{$\begin{array}{c}\text { Tekno-Aşırı } \\
\text { Yükleme }\end{array}$} & \multicolumn{2}{|c|}{ Tekno-Belirsizlik } & \multicolumn{2}{|c|}{ Tekno-Karmaşıklık } & \multicolumn{2}{|c|}{ Teknostres } \\
\hline & $\overline{\mathbf{x}}$ & ss & $\overline{\mathbf{x}}$ & SS & $\overline{\mathbf{x}}$ & ss & $\overline{\mathbf{x}}$ & SS \\
\hline Lise & 2,46 & 0,91 & 2,39 & 0,86 & 2,16 & 0,62 & 2,33 & 0,57 \\
\hline Ön Lisans & 2,70 & 1,06 & 2,90 & 0,83 & 2,40 & 0,85 & 2,65 & 0,62 \\
\hline Lisans & 2,59 & 0,75 & 3,00 & 0,93 & 2,25 & 0,61 & 2,58 & 0,55 \\
\hline Yüksek Lisans & 2,12 & 1,05 & 2,93 & 0,97 & 2,10 & 0,48 & 2,34 & 0,58 \\
\hline $\begin{array}{l}\text { Doktora/Tipta } \\
\text { Uzmanlık }\end{array}$ & 2,18 & 0,90 & 3,33 & 0,79 & 2,02 & 0,72 & 2,45 & 0,49 \\
\hline f değeri & \multicolumn{2}{|c|}{1,502} & \multicolumn{2}{|c|}{4,394} & \multicolumn{2}{|c|}{1,328} & \multicolumn{2}{|c|}{2,039} \\
\hline p değeri & \multicolumn{2}{|c|}{0,205} & \multicolumn{2}{|c|}{0,002} & \multicolumn{2}{|c|}{0,262} & \multicolumn{2}{|c|}{0,092} \\
\hline
\end{tabular}

Katılımcıların öğrenim düzeylerine göre tekno-belirsizlik puan ortalamaları anlamlı bir şekilde farklılaşmaktadır $(\mathrm{f}=4,394 ; \mathrm{p}<0,05)$. Bu farkın lise-ön lisans, lise-lisans ve lise-doktora/tıpta uzmanlık öğrenim düzeyine sahip katılımcılardan kaynakladığı tespit edilmiştir. Lise düzeyinde eğitime sahip kişilerin tekno-belirsizlik ortalamasının $(\overline{\mathrm{x}}=2,39)$, ön lisans $(\overline{\mathrm{x}}=2,90)$, lisans $(\overline{\mathrm{x}}=3,00)$ ve doktora/tıpta uzmanlık $(\overline{\mathrm{x}}=3,33)$ düzeyinde eğitime sahip kişilerden düşük olduğu tespit edilmiştir. Bu sonuçlar doğrultusunda, $\mathbf{H}_{3}$ hipotezi kısmen desteklenmiştir.

Katılımcıların teknostres, tekno-karmaşıklık, tekno-belirsizlik ve tekno-aşırı yükleme ortalamalarının, katılımcıların mesleklerine göre farklılaşıp farklılaşmadığını belirlemek amacıyla tek yönlü varyans analizi yapılmıştır. Bu analizin sonuçlarına Tablo 7'de yer verilmiştir.

Tablo 7: Mesleğin Tekno-Aşırı Yükleme, Tekno-Belirsizlik, Tekno Karmaşıklık ve Teknostres Üzerindeki Etkisi

\begin{tabular}{|c|c|c|c|c|c|c|c|c|}
\hline \multirow{2}{*}{ Kategori } & \multicolumn{2}{|c|}{$\begin{array}{l}\text { Tekno-Aşırı } \\
\text { Yükleme }\end{array}$} & \multicolumn{2}{|c|}{ Tekno-Belirsizlik } & \multicolumn{2}{|c|}{ Tekno-Karmaşıklık } & \multicolumn{2}{|c|}{ Teknostres } \\
\hline & $\overline{\mathbf{x}}$ & Ss & $\overline{\mathbf{x}}$ & SS & $\overline{\mathbf{x}}$ & ss & $\overline{\mathbf{x}}$ & SS \\
\hline Hekim & 2,13 & 0,95 & 3,35 & 0,87 & 2,01 & 0,69 & 2,44 & 0,53 \\
\hline Hemşire & 2,52 & 0,99 & 2,74 & 0,93 & 2,35 & 0,78 & 2,52 & 0,66 \\
\hline $\begin{array}{l}\text { Yard. Sağlık } \\
\text { Personeli }\end{array}$ & 2,75 & 1,00 & 2,88 & 1,09 & 2,55 & 0,97 & 2,72 & 0,65 \\
\hline İdari Görevli & 2,47 & 1,02 & 2,84 & 0,79 & 2,38 & 0,72 & 2,54 & 0,60 \\
\hline $\begin{array}{l}\text { Hasta Kayit } \\
\text { Yetkilisi }\end{array}$ & 3,07 & 0,84 & 2,65 & 0,94 & 2,13 & 0,70 & 2,62 & 0,47 \\
\hline $\begin{array}{l}\text { Hasta } \\
\text { Danıșmanı }\end{array}$ & 2,70 & 0,82 & 2,73 & 0,83 & 2,22 & 0,60 & 2,54 & 0,59 \\
\hline Ebe & 3,10 & 1,27 & 3,00 & 0,35 & 2,20 & 0,56 & 2,75 & 0,35 \\
\hline f değeri & \multicolumn{2}{|c|}{1,290} & \multicolumn{2}{|c|}{1,349} & \multicolumn{2}{|c|}{1,467} & \multicolumn{2}{|c|}{0,566} \\
\hline p değeri & \multicolumn{2}{|c|}{0.259} & \multicolumn{2}{|c|}{0,232} & \multicolumn{2}{|c|}{0,184} & \multicolumn{2}{|c|}{0.783} \\
\hline
\end{tabular}

Katılımcıların mesleklerine göre genel teknostres puan ortalaması ve teknostres alt boyut puan ortalamaları istatistiksel olarak anlamlı bir şekilde farklılaşmamaktadır $(p>0,05)$. Bu sonuçlar doğrultusunda, $\mathbf{H}_{4}$ hipotezi reddedilmiştir.

Katılımcıların teknostres, tekno-karmaşıklık, tekno-belirsizlik ve tekno-aşırı yükleme puan ortalamalarının, katılımcıların aylık gelirlerine göre farklılaşıp farklılaşmadığını belirlemek amacıyla tek yönlü varyans analizi yapılmıştır. Bu analizin sonuçlarına Tablo 8'de yer verilmiştir. 
Tablo 8: Aylık Gelirin Tekno-Aşırı Yükleme Tekno-Belirsizlik, Tekno-Karmaşıklık ve Teknostres Üzerindeki Etkisi

\begin{tabular}{|c|c|c|c|c|c|c|c|c|}
\hline \multirow{2}{*}{ Kategori } & \multicolumn{2}{|c|}{$\begin{array}{c}\text { Tekno-Aşırı } \\
\text { Yükleme }\end{array}$} & \multicolumn{2}{|c|}{ Tekno-Belirsizlik } & \multicolumn{2}{|c|}{ Tekno-Karmaşıklık } & \multicolumn{2}{|c|}{ Teknostres } \\
\hline & $\overline{\mathbf{x}}$ & SS & $\overline{\mathbf{x}}$ & SS & $\overline{\mathbf{x}}$ & SS & $\overline{\mathbf{x}}$ & SS \\
\hline Düşük & 2,67 & 0,98 & 2,68 & 0,89 & 2,25 & 0,75 & 2,52 & 0,62 \\
\hline Orta & 2,41 & 0,90 & 2,92 & 0,81 & 2,20 & 0,69 & 2,48 & 0,52 \\
\hline Yüksek & 2,09 & 1,01 & 3,52 & 0,83 & 2,18 & 0,70 & 2,53 & 0,53 \\
\hline f değeri & \multicolumn{2}{|c|}{2,472} & \multicolumn{2}{|c|}{5,051} & \multicolumn{2}{|c|}{0,116} & \multicolumn{2}{|c|}{0,092} \\
\hline p değeri & \multicolumn{2}{|c|}{0,088} & \multicolumn{2}{|c|}{$\mathbf{0 , 0 0 8}$} & \multicolumn{2}{|c|}{0,890} & \multicolumn{2}{|c|}{0,912} \\
\hline
\end{tabular}

Katılımcıların aylık gelirine göre tekno-belirsizlik puan ortalaması istatistiksel olarak anlamlı bir şekilde farkl1lık göstermektedir $(\mathrm{f}=5,051 ; \mathrm{p}<0,05)$. Fark, gelirini düşük olarak ifade edenler ile gelirini yüksek olarak ifade edenlerden kaynaklanmaktadır. Gelirini düşük olarak ifade edenlerin tekno-belirsizlik puan ortalaması $(\overline{\mathrm{x}}=2,68)$ gelirini yüksek olarak ifade edenlere $(\overline{\mathrm{x}}=3,52)$ göre daha düşük olarak tespit edilmiştir. Bu sonuçlar doğrultusunda, H5 hipotezi kısmen desteklenmiştir.

Katılımcıların yaş, kurumda çalışma süresi ve meslekte çalışma sürelerinin teknostres, tekno-aşırı yükleme, tekno-karmaşıklık ve tekno-belirsizlik puan ortalamaları ile ilişkileri incelenmiş ve Tablo 9'da sunulmuştur.

Tablo 9: Yaş, Kurumda Çalışma Süresi, Meslekte Çalışma Süresi, Tekno-Aşırı Yükleme, TeknoBelirsizlik, Tekno-Karmaşıklık ve Teknostres İlişkisi

\begin{tabular}{|c|c|c|c|c|c|c|c|}
\hline & 1 & 2 & 3 & 4 & 5 & 6 & 7 \\
\hline 1)Yaş & 1 & & & & & & \\
\hline 2)Kurumda Çalışma Süresi & $0,466 * *$ & 1 & & & & & \\
\hline 3)Meslekte Çalışma Süresi & $0,925 * *$ & $0,573^{* *}$ & 1 & & & & \\
\hline 4)Tekno-Aşırı Yükleme & $-0,142$ & 0,098 & $-0,610$ & 1 & & & \\
\hline 5)Tekno-Belirsizlik & 0,144 & $-0,620$ & 0,092 & $-0,005$ & 1 & & \\
\hline 6)Tekno-Karmaşıklık & $-0,158^{*}$ & $-0,690$ & $-0,084$ & $0,387^{* *}$ & $0,192^{*}$ & 1 & \\
\hline 7)Teknostres & $-0,091$ & 0,000 & $-0,034$ & $0,758 * *$ & $0,512 * *$ & $0,753 * *$ & 1 \\
\hline
\end{tabular}

*: Korelasyon 0,05 düzeyinde anlamlı. **: Korelasyon 0,01 düzeyinde anlamlı.

Yapılan pearson korelasyon analizi sonucunda, katılımcıların kurumda çalışma süreleri ve meslekte çalışma süreleri ile teknostres, tekno-aşırı yükleme, tekno-karmaşıklık ve tekno-belirsizlik puan ortalamaları arasında istatistiksel olarak anlamlı bir ilişki tespit edilmemiştir ( $\mathrm{p}>0,05)$. Bu sonuçlar doğrultusunda, $\mathbf{H}_{6}$ ve $\mathbf{H}_{7}$ hipotezleri reddedilmiştir.

Yapılan pearson korelasyon analizi sonucunda, yaş ile tekno-karmaşıklık arasında istatistiksel olarak anlamlı ve negatif yönde çok zayıf bir ilişki tespit edilmiştir $(r=-0,158 ; p<0,05)$. Dolayısı ile, katılımcıların yaşları arttıkça tekno-karmaşıklık puan ortalamaları azalmaktadır. Bu sonuçlar doğrultusunda ise, $\mathbf{H}_{8}$ hipotezi kısmen desteklenmiştir.

Yapılan istatistiki analizler sonucunda genel olarak; $\mathrm{H}_{1}, \mathrm{H}_{3}, \mathrm{H}_{5}$ ve $\mathrm{H}_{8}$ hipotezleri kısmen desteklenmiş, $\mathrm{H}_{2}, \mathrm{H}_{4}, \mathrm{H}_{6}$ ve $\mathrm{H}_{7}$ hipotezleri ise reddedilmişstir.

\section{Tartışma ve Sonuç}

İnsan davranışları, düşünceleri, tutumları ve psikolojisi üzerindeki artan teknoloji kullanımının getirdiği olumsuz etkiler teknostresi ifade etmektedir (Nisafani, Kiely ve Mahony, 2020: 2). Sağlik sektöründe hastanelerin dijital olma seviyelerinin artması ve artan BİT kullanımı (HIMSS, 2020) teknostres konusunu daha önemli bir hale getirmiştir. Bu çalışmada, bir özel hastanede görev yapan 
sağlık çalışanlarının $(n=159)$ teknostres düzeylerinin tespit edilmesi ve sağlık çalışanlarının çeşitli demografik ve mesleki özelliklerinin teknostres düzeyleri üzerindeki etkisinin ortaya konması amaçlanmıştır. $\mathrm{Bu}$ kapsamda çalışanların demografik ve mesleki özelliklerinin teknostres düzeylerine olan etkisi incelemek amacıyla yapılan analizler sonucunda; çalışanların teknobelirsizlik düzeyinin cinsiyet, öğrenim düzeyi ve aylık gelire göre farklılık gösterdiği ve ayrıca çalışanların yaşları ile tekno-karmaşıklık düzeyleri arasında negatif yönlü bir ilişkinin varlığı tespit edilmiştir (Tablo 4; Tablo 6; Tablo 8; Tablo 9). Buna karşın teknoloji eğitimi, meslek, kurumda çalışma süresi ve meslekte çalışma süresinin teknostres üzerinde herhangi bir etkiye sahip olmadığ1 görülmüştür (Tablo 5; Tablo 7; Tablo 9). Ayrıca sağlık çalışanlarının teknostres düzeyleri incelendiğinde ise teknostres puan ortalamaları $2,52 \pm(0,59)$ olmak üzere ortalama bir teknostres düzeyine sahip oldukları görülmüştür (Tablo 3).

Literatürde teknostresin ve alt boyutlarının cinsiyete göre farklılaştığı görülmüştür (Akgün, 2019; Doğrular, 2019; Kaymaz, 2019; La Torre vd., 2019; Sever ve Sever, 2017; Türen vd., 2015; Çoklar ve Şahin, 2011; Tarafdar vd., 2011; Ragu-Nathan vd., 2008). Bu çalışmada da tekno-belirsizlik boyutunun cinsiyete göre farklılaştığı ve erkeklerin tekno-belirsizlik puan ortalamalarının $(3,15 \pm 0,87)$ kadınlarınkine $(2,76 \pm 0,87)$ göre daha fazla olduğu tespit edilmiştir (Tablo 4). Literatürde kadınların erkeklere göre daha çok teknostrese maruz kaldıklarını destekleyen çalışmalar da mevcuttur (Akgün, 2019; La Torre vd., 2019; Rajput, Gupta ve Kesharwani, 2011). Ancak çalışmanın bu bulgusu genel olarak alan yazını destekler niteliktedir (Sever ve Sever, 2017; Türen vd., 2015; Çoklar ve Şahin, 2011; Ragu-Nathan vd., 2008). Ayrıca sağlık sektöründe Doğrular (2019)'un yaptığ ç̧alışmada da erkeklerin tekno-belirsizlik düzeylerinin kadınlara göre daha yüksek olduğu görülmüştür. Burada kadınların sağlık sektöründe yoğun olarak ebe ve hemşire pozisyonunda olması ve sahada olması sebebi ile teknoloji kullanımlarının daha düşük olması sağlık sektörüne özgü olarak bu duruma neden olduğu şeklinde yorumlanabilir (Doğrular, 2019).

Çalışmanın bir diğer bulgusuna göre çalışanların öğrenim düzeylerine göre tekno-belirsizlik ortalamaları farklılaşmaktadır. Bu farkın lise-ön lisans, lise-lisans ve lise-doktora/tıpta uzmanlık öğrenim düzeyine sahip katılımcılardan kaynakladığı tespit edilmiştir. Yüksek eğitim düzeyine sahip çalışanların daha yüksek tekno-belirsizlik puan ortalamasına sahip oldukları görülmüştür (Tablo 6). Çalışmanın bu bulguları literatürdeki çalışmaları desteklemektedir (La Torre vd., 2019; Türen vd., 2015). Bu durum, öğrenim düzeyi yüksek olan kişilerin teknolojik yenilikler ile ilgili daha çok bilgiye sahip oldukları, dolayısı ile sağlıta değişen teknolojiye sürekli ayak uydurmaya çalışmalarının da tekno-belirsizlik seviyelerini yükselteceği şeklinde yorumlanabilir. Buradan hareketle eğitim düzeyi yüksek çalışanlara hastanelerin insan kaynakları birimleri tarafından sürekli gelişen ve değişen teknoloji ile ilgili periyodik eğitim verilmesi önerilebilir.

Literatürde yer alan çalışmalarda teknostresin ve alt boyutlarının aylık gelire göre değişebileceği ifade edilmektedir (Çoban, 2019; La Torre, 2019; Hsiao, 2016; Şahin ve Çoklar, 2009). Bu çalışmada da kişilerin tekno-belirsizlik düzeyleri aylık gelire göre farklılaşmaktadır. Gelirini yüksek olarak ifade edenlerin tekno-belirsizlik düzeyleri, gelirlerini düşük olarak ifade edenlere göre daha yüksektir. Çalışmanın bu bulgusu literatürdeki diğer çalışmalar ile uyuşmamaktadır (Çoban, 2019; Hsiao, 2016; Şahin ve Çoklar, 2009). Şahin ve Çoklar (2009) tarafindan yapılan çalışmada sosyal ağ kullanıcılarının artan gelirleri teknostres düzeylerini düşürmektedir. Bu durum kullanıcıların farklı teknolojileri bireysel olarak deneme imkânı olmasından kaynaklandı ğ şeklinde yorumlanmıştır. Fakat sağlık sektöründe yer alan teknolojilerin sağlık çalışanları tarafından bireysel olarak kullanılması mümkün gözükmemektedir.

Yapılan çalışma sonucunda yaş ile tekno-karmaşıklık arasında istatistiksel olarak anlamlı ve negatif yönde çok zayıf bir ilişki tespit edilmiştir $(r=-0,158$; $\mathrm{p}<0,05)$. Korelasyon analizinde $r$ katsayısı pozitif ve negatif olmak üzere 0 ile 1 arasında bir değer almaktadır. Bu aralıktaki değerler; 0-0,2 arası çok zayıf, 0,2-0,4 arası zayıf, 0,4-0,6 arası orta, 0,6-0,8 arası kuvvetli, 0,8-1 arası ise tam ilişki 
olarak sınıflandırılmaktadır (Kaptanoğlu, 2013: 177). Literatürdeki çalışma sonuçları incelendiğinde yaş ile teknostres ve alt boyutları arasında ilişkinin var olduğu gözlenmiştir (Kaymaz, 2019; La Torre vd., 2019; Özbozkurt, 2019; Çetin ve Bülbül, 2017; Çoklar ve Şahin, 2011; Tarafdar vd., 2011; Şahin ve Çoklar, 2009; Ragu-Nathan vd., 2008). Yapılan çalışma sonucunda yaş arttıkça tekno-karmaşıklık düzeyinin azaldığı tespit edilmiştir (Tablo 9). Bu sonuç literatürde yer alan diğer çalışmaları destekler niteliktedir (Özbozkurt, 2019; Çetin ve Bülbül, 2017; Şahin ve Çoklar, 2009). Yaşın artması ile tekno-karmaşıklık seviyelerinin azalmasının kişilerin kazandıkları deneyimlerle ilgili olduğu düşünülmektedir (Şahin ve Çoklar, 2009). Bu doğrultuda daha yaşlı ve deneyimli çalışanların koçluk ve mentorluk gibi uygulamalarla genç ve deneyimsiz çalışanlara destek olması önerilebilir.

Sağlık çalışanlarının BİT'e dair eğitilmelerinin teknostresin artışını engellemeye katkıda bulunduğunu ortaya koyan çalışmalar (Sami ve Pangannaiah, 2006: 434) olmasına karşın; bu çalışmada sağlık çalışanlarının teknoloji ile ilgili eğitim alma durumunun teknostres düzeylerini etkilemediği görülmüştür. Bu bulgu literatürde yer alan çalışma sonuçları ile çelişmektedir (Çetin ve Bülbül, 2017). Çeşitli eğitim programlarına rağmen, birçok kuruluştaki çalışan, teknostresle baş edememekte ve kendilerini rahat hissedememektedir (Lalitha ve Pangannaiah, 2006). Sağlık çalışanlarının aldıkları teknoloji eğitiminin kapsamı, kalitesi ve yeterliliği gibi çeşitli özelliklerinin gözden geçirilerek geliştirilmesi önerilebilir.

Literatürde, kurumda ve meslekte çalışma süresinin teknostres düzeyini etkilediği belirtilmiştir (Kaymaz, 2019; Çetin ve Bülbül, 2017). Ancak bu çalışmada kurumda ve meslekte çalışma süresi ile teknostres düzeyi arasında herhangi bir ilişki tespit edilememiş olup bu bulgu literatürü destekler nitelikte değildir (Tablo 9).

Sağlık sektörü dışındaki sektörlerde yapılan çalışmalar sonucunda katılımcıların teknostres düzeylerinin mesleklerine göre farklılaştığı görülmektedir (Kaymaz, 2019; La Torre vd., 2019; Türen vd., 2015, Çoklar ve Şahin, 201). Ancak bu çalışma sonucunda mesleklere göre teknostres düzeylerinde bir farklılık görülmemiştir (Tablo 7). Dolayısı ile literatürde yer alan bulgularla yapılan bu çalışmanın bulguları örtüşmemektedir. Sağlık sektöründe çalışanların mesleklerine (hekim, hemşire, ebe, yardımcı sağlık personeli vb.) bağlı olarak kullanacağı teknolojinin de farklılaşması ve bunun da teknostres düzeylerini etkilemesi beklenen bir durumdur. Ancak bir sistem olarak değerlendirildiğinde sağlık sektörünün çıktısı sağlıklı olma hali olarak kabul edilmekte ve herhangi bir hata sonucunda ölüm gibi ciddi sonuçlar doğurması nedeniyle her sağlık çalışanının yoğun olarak çaba sarf etmesini gerektirmektedir. Bu durumun da mesleklere göre bir farkın ortaya çıkmamasına etki ettiği düşünülmektedir.

Sonuç olarak teknostresin pek çok olumsuz sonucu mevcuttur. Bu çalışmada ise yaş, meslek, öğrenim düzeyi, meslekte ve kurumda çalışma süresi, cinsiyet, teknoloji ile ilgili eğitim alma ve aylık gelir değişkenlerinin teknostres üzerindeki etkileri ele alınmıştır. Teknostresin olumsuz sonuçlarının ortadan kaldırılması ya da teknostresin etkin bir şekilde yönetilebilmesi için çalışanların teknostres düzeylerini etkileyebilecek faktörlerin bilinmesi ve bu faktörlerin teknostres üzerinde ne tür bir etkisinin olacağının bilinmesi önemlidir. Sağlık kurumlarının teknostresi etkileyecek bu faktörleri tespit ve ayırt ederek yönetim faaliyetlerini düzenlemeleri gerekmektedir. Böylelikle kurum içinde fiziksel, psikolojik ve davranışsal açıdan daha sağlıklı çalışanların olması ve daha pozitif bir çalışma ortamı yaratılması mümkün olabilir.

$\mathrm{Bu}$ çalışmada birtakım sınırlılıklar mevcuttur. Bunlardan biri katılımıı sayısının az olması ve çalışmanın yalnızca bir özel hastanede gerçekleştirilmesidir. Dolayısı ile bu sinırlılık çalışma bulgularının yalnızca çalışmanın gerçekleştiği hastaneye genellenmesini mümkün kılmaktadır. Ayrıca çalışmanın yapıldığı özel hastanede, sağlık çalışanlarının teknoloji kullanım düzeyleri sınıflandırılmamıştır. Dolayısı ile hangi çalışan grubunun ne düzeyde ve yoğunlukta teknoloji kullandıkları bilinmemektedir. Gelecek çalışmalarda örneklem sayısının arttırılması ve 
katılımcıların teknoloji kullanımlarına göre sınıflandırılmış tabakalı örnekleme yöntemi ile belirlenmesi önerilmektedir. Aynı zamanda bu çalışma çeşitli demografik ve mesleki faktörlerin teknostres üzerindeki etkilerini ortaya koymaktadır. Buna ek olarak sonraki çalışmalarda teknostresin sağlı sektöründe ne tür sonuçlara yol açabileceğini ortaya koyan çalışmaların yapılması önerilmektedir.

\section{KAYNAKÇA}

Akgün, F. (2019). Öğretim Elemanlarının Bilgi ve İletişim Teknolojilerine Yönelik Kabulleri ve Teknostres Algıları Arasındaki İlişsinin İncelenmesi. Eğitim Bilimleri Araştırmaları Dergisi, 9(2), 40-66.

Ayyagari, R., Grover, V., \& Purvis, R. (2011). Technostress: technological antecedents and implications. MIS quarterly, 35(4), 831-858.

Berger, R., Romeo, M., Gidion, G., \& Poyato, L. (2016). Media use and technostress. İçinde L. Gómez Chova, A. López Martínez \& I. Candel Torres (Eds.), INTED 2016 proceedings. 10th International Technology, Education and Development Conference. Valencia: IATED Academy.

Christian, M., Purwanto, E., \& Wibowo, S. (2020). Technostress Creators on Teaching Performance of Private Universities in Jakarta During Covid-19 Pandemic. Technology Reports of Kansai University, 62(6), 2799-2809.

Çetin, D. ve Bülbül, T. (2017). Okul yöneticilerinin teknostres algıları ile bireysel yenilikçilik özellikleri arasındaki ilişkinin incelenmesi. Abant İzet Baysal Üniversitesi Eğitim Fakültesi Dergisi. 17(3), 1241-1264.

Çiçek, B., \& Kılınç, E. (2020). Teknostresin presenteizm ve işten ayrılma niyetine etkisinde dönüşümcü liderliğin arac1 rolü. Business and Economics Research Journal, 11(2), 555-570.

Çoban, İ. (2019). Teknolojik Değişimin Hastane Çalışanları Üzerine Etkileri: Bir Devlet Hastanesi Örneği (Yayımlanmamış yüksek lisans tezi). Kırklareli Üniversitesi. Sağlık Bilimleri Enstitüsü. Hemşirelik Anabilim Dalı, Kırklareli.

Çoklar, A. N., ve Şahin, Y. L. (2011). Technostress levels of social network users based on ICTs in Turkey. European Journal of Social Sciences, 23(2), 171-182.

Çoklar, A., Efilti, E., Şahin, Y., \& Akçay, A. (2016). Determining the reasons of technostress experienced by teachers: a qualitative study. Turkish online journal of qualitative inquiry, 7(2), 71-96.

Davis, L.D. \& Davis, F.D. (1990). The effect of training techniques and personal characteristics on training end users of information system. Journal of Management Information System, 7, 93110.

Doğrular, M. M. (2019). Teknostresin verimlilik üzerine etkisi. Marmara Üniversitesi. Sağlık Bilimleri Enstitüsü. Hastane İşletmeciliği Anabilim Dalı, İstanbul.

Dragano, N., \& Lunau, T. (2020). Technostress at work and mental health: concepts and research results. Current Opinion in Psychiatry, 33(4), 407-413.

Durmuş, B., Yurtkoru, S. \& Çinko, M. (2016). Sosyal bilimlerde SPSS'le veri analizi. İstanbul: Beta Basım. 
Fischer, T., \& Riedl, R. (2017). Technostress research: A nurturing ground for measurement pluralism?. Communications of the Association for Information Systems, 40(1), 17.

Göktaş, B., Önder, Ö.R., Duran, M., Şakar, S., Yılmaz, M., Güler, S., Çınar İ, Çamlıdağ T, Şenkal Y, \& Özdemir, G. (2017). Türkiye'de Sağlık Bilgi Sistemleri Üzerine Bir Araştırma. Ankara Să̆llk Bilimleri Dergisi, (1-2-3), 125-138

Güğerçin, U. (2020). Does techno-stress justify cyberslacking? An empirical study based on the neutralisation theory. Behaviour \& Information Technology, 39(7), 824-836.

HIMSS. (2020). Erişim Adresi: https://himsseurasia.com/himss-analitik-nedir/ Erişim tarihi: 11.08.2020.

Hsiao, K. L., Lee, C. H., Chiang, H. S., \& Wang, J. Y. (2016).Compulsive mobile application usage and technostress: The role of personality traits. Online Information Review, 41(2), 284.

Jena, R. K., \& Mahanti, P. K. (2014). An Empirical study of Technostress among Indian Academicians. 3(2), 1-10.

Kaptanoğlu, A.Y. (2013). Sağlık Alanında Hipotezden Teze: Veri Toplama ve Çözümleme Serüveni (1b.). İstanbul: Beşir Kitabevi.

Kaymaz, O. (2019). Teknostres ve iş güvencesizliği ilişkisine yönelik bir uygulama. (Yayımlanmamış yüksek lisans tezi). Trakya Üniversitesi. Sosyal Bilimler Enstitüsü. İşletme Anabilim Dalı, Trakya.

Keleş, D. (2019). Öğretmen Adaylarının Tekno-stres Íncelenmesi:Dijital Hikaye Örneği. (Yayımlanmamış yüksek lisans tezi). Kastamonu Üniversitesi. Fen Bilimleri Enstitüsü. İlköğretim Anabilim Dalı, Kastamonu.

Khan, A. A., Jamil, A., \& Bakhsh, K. (2020). Role of Organizational Environment in Reducing the Effect of Techno-Stress on Work Behavior of the University Teachers. Global Social Sciences Review, 1, 313-321.

Kim, H.J., Lee, C.C., Yun, H., \& Shin, I.K. (2015). An examination of work exhaustion in the mobile enterprise environment. Technological Forecasting \& Social Change, 100, 255-266.

Kushlev, K., \& Dunn, E. W. (2015). Checking email less frequently reduces stress. Computers in Human Behavior, 43, 220-228.

La Torre, G., Esposito, A., Sciarra, I., \& Chiappetta, M. (2019). Definition, symptoms and risk of techno-stress: a systematic review. International archives of occupational and environmental health, 92(1), 13-35.

Lalitha, ve Pangannaiah, (2006). "Technostress, A literature survey on the effect of information technology on library users", Library Review, 55(7). 429-439.

Mahboob, A., \& Khan, T. (2016). Technostress and Its Management Techniques: A Literature. Journal of Human Resource Management, 4(3), 28-31.

Nimrod, G. (2018). Technophobia among older Internet users Technophobia among older Internet users Galit Nimrod. Educational Gerontology, 44(2-3), 148-162. https://doi.org/10.1080/03601277.2018.1428145

Nisafani, A. S., Kiely, G., \& Mahony, C. (2020). Workers' technostress: a review of its causes, strains, inhibitors, and impacts. Journal of Decision Systems, 1-16.

Özbozkurt, O.B. (2019). Teknostres ve Verimlilik Arasındaki İlişkinin Incelenmesi Üzerine Bir Araştırma. Bursa: Ekin Yayınevi 
Ragu-Nathan, T. S., Tarafdar, M., Ragu-Nathan, B. S., \& Tu, Q. (2008). The consequences of technostress for end users in organizations: Conceptual development and empirical validation. Information systems research, 19(4), 417-433.

Rajput, N., Gupta, M., \& Kesharwani, S. (2011). Techno Stress in Gender Perspective: An Empirical Investigation. Global Journal of Enterprise Information System, 3(4), 12-21.

Salo, M., Pirkkalainen, H., Chua, C., \& Koskelainen, T. (2017). Explaining Information Technology Users'ways Of Mitigating Technostress. İçinde 25. European Conference on Information Systems (ECIS), Guimarães, Portugal, June 5-10, 2017 (ss. 2460-2476).

Sami, L.K. ve Pangannaiah, N.B. (2006), "“Technostress" A literature survey on the effect of information technology on library users", Library Review, 55(7), ss. 429-439.

Sellberg, C., \& Susi, T. (2014). Technostress in the office: a distributed cognition perspective on human-technology interaction. Cognition, Technology \& Work, 16(2), 187-201.

Sever, H., \& Sever, (2017). Ergonomi ve Teknostresin Sivil Havac1lık Sektöründeki Etkisi. Ejovoc (Electronic Journal of Vocational Colleges), 7(1), 39-46.

Tabachnick, B. G., \& Fidell, L. S. (2013). Using Multivariate Statistics, 6. Bask1, Pearson Education. Inc, Boston.

Tarafdar, M., Ragu-nathan, B. S., \& Tu, Q. (2018). The consequences of technostress for end users in organizations: Conceptual development and Empirical Validation. 19(4), 417-433. https://doi.org/10.1287/isre.1070.0165

Tarafdar, M., Tu, Q., Ragu-Nathan, B. S. and Ragu-Nathan, T. (2007). The impact of technostress on role stress and productivity. Journal of Management Information Systems, 24 (1), 301-328.

Tarafdar, M., Tu, Q., Ragu-Nathan, T. S., \& Ragu-Nathan, B. S. (2011). Crossing to the dark side: examining creators, outcomes, and inhibitors of technostress. Communications of the ACM, 54(9), 113-120.

Türen, U., Erdem, H., \& Kalkın, G. (2015). İş Yerinde Tekno-Stres Ölçeği: Havacılık ve Bankacılık Sektöründe Bir Araştırma. Çalışma İlişkileri Dergisi, 6(1), 1-19.

Wang, X., Tan, S. C., \& Li, L. (2020). Measuring university students' technostress in technologyenhanced learning: Scale development and validation. Australasian Journal of Educational Technology, 96-112.

Weinert, C., Christian, M., Laumer, S., \& Weitzel, T. (2020).Technostress mitigation: an experimental study of social support during a computer freeze. Journal of Business Economics, 1-51.

Yener, Ü. S. (2018). Teknostresin İş Performansı Üzerindeki Etkisi; Tükenmişliğin Aracı Rolü. Afyon Kocatepe University Journal of Social Sciences, 20(2). 85-101.

Zwanenburg, S. P. (2013). Information Technology Addiction: Construct Development and Effects on Work Performance. Icis-Rp, 1(4). 21-37. 